\title{
CLINICAL MARKERS OF IMMUNE DISORDERS IN THE PATHOGENESIS OF ESCHERICHIA COLI ENTERITIS
}

\author{
Larysa P. SYDORCHUK ${ }^{\circledR}$, Boris V. SYROTA ${ }^{1}$, Andrii R. SYDORCHUK ${ }^{1}$, Oleg V. GERUSH ${ }^{2}$, \\ Natalia Y. MUZYKA ${ }^{2}$, Michael I. SHEREMET ${ }^{4}$, Oksana M. KOROVENKOVA ${ }^{2}$, \\ Natalia S. BOHDAN ${ }^{2}$, Olha Y. SKRYNCHUK ${ }^{2}$, Liviya V. NIKYFOR ${ }^{1}$, Oksana M. IFTODA ${ }^{3}$, \\ Serhiy I. IVASHCHUK ${ }^{1}$, Oksana V. KUSHNIR ${ }^{3}$
}

${ }^{1}$ Department of Family Medicine, Higher State Educational Establishment of Ukraine «Bukovinian State Medical University» (BSMU), Ukraine

${ }^{2}$ Pharmacology Department, BSMU, Ukraine

${ }^{3}$ Hygiene and Ecology Department, BSMU, Ukraine

${ }^{4}$ Surgery Department Nº1, BSMU, Ukraine

\section{Abstract}

Background. Escherichia coli enteritis is one of the most common causes of diarrhea in developed countries and is caused usually by pathogenic strains of Escherichia coli.

Objectives. To investigate the role of reactive response of polymorphonuclear neutrophilic granulocytes (NG) of peripheral blood in the systemic inflammatory response mechanisms of acute Escherichia enterocolitis (AEC), depending on genes polymorphism of heat shock proteins (HSP) family 70-2 (HSP70-2, 1267A®G) and interleukin 10 (IL-10, C-592A).

Material and methods. The genes polymorphism was analysed by PCR based method in 95 patients with $\mathrm{AEC}$ and 30 healthy individuals. Clinical markers of immune disorders were evaluated after hematological indices, based upon an extended general clinical blood analysis, using verified formulas.

Results. The endogenous intoxication severity did not depend reliably on genotypes of IL-10 gene (rs1800872), however it was significantly $23.68 \%$

\section{RÉsumÉ}

Marqueurs cliniques des troubles immunitaires dans la pathogenèse de la coli entérite

Introduction. La coli entérite est l'une des causes les plus courantes de diarrhée dans les pays développés et est généralement causée par des souches pathogènes d'Escherichia coli.

Objectif: étudier le rôle de la réponse réactive des granulocytes neutrophiles polymorphonucléaires (GN) du sang périphérique dans les mécanismes de réponse inflammatoire systémique de l'entérocolite aiguë d'Escherichia (AEC) en fonction du polymorphisme des gènes de la protéine de choc thermique (HSP) de la famille 70-2 (HSP70-2, 1267A®G) et l'interleukine 10 (IL-10, C-592A).

Méthodes. Le polymorphisme des gènes a été analysé par la méthode basée sur la PCR chez 95 patients avec $\mathrm{AEC}$ et 30 individus en bonne santé. Les marqueurs cliniques des troubles immunitaires ont été évalués à l'aide d'indices hématologiques, basés sur une analyse 
( $\mathrm{p}=0.043)$ higher in GG-genotype carriers of HSP70-2 gene (rs1061581). The reduction of cellular reactivity by $14.71-19.08 \%(p<0.01)$ did not depend on the analyzed genes genotypes. But general non-specific immune reactivity decreases 3.49-4.24 times $(\mathrm{p}<0.001)$ was deeper in GG-genotype carriers of HSP70-2 gene and AA-genotype carriers of IL-10 gene by $17.78 \%$ $(p=0.009)$ and $12.37 \%(p=0.023)$ respectively. The immunologic resistance index was lower by $18.75 \%$ $(p=0.024)$ in GG-genotype carriers than in patients with $A$ allele.

Conclusions. Hematological indices, based upon an extended general clinical blood analysis, are indicative and reliable non-specific clinical markers of immune disorders in case of AEC.

Keywords: markers, immune disorders, genes IL-10 (rs1800872), HSP70-2 (rs1061581), E. coli enteritis.

Abbreviations: AEC - acute Escherichia coli enterocolitis, HSP - heat shock proteins, IL - interleukin, ICC - immune-competent cells, LII - leukocyte intoxication index, LPS - lipopolysaccharides, NG - neutrophilic granulocytes. sanguine clinique générale étendue, à l'aide de formules vérifiées.

Résultats. La sévérité de l'intoxication endogène ne dépendait pas de manière fiable des génotypes du gène IL-10 (rs1800872), cependant elle était significativement supérieure de $23,68 \%(p=0,043)$ chez les porteurs du génotype GG du gène HSP70-2 (rs1061581). La réduction de la réactivité cellulaire de 14,71 à $19,08 \%(\leq<0,01)$ ne dépendait pas des génotypes des gènes analysés. Mais la réactivité immunitaire non spécifique générale a diminué de 3,49 à 4,24 fois ( $\leq$ $<0,001$ ) chez les porteurs du génotype GG du gène HSP70-2 et du génotype AA du gène de l'IL-10 de $17,78 \%(\leq=0,009)$ et de $12,37 \%$. $(==0,023)$ respectivement. L'indice de résistance immunologique était inférieur de $18,75 \%(\mathrm{p}=0,024)$ chez les porteurs du génotype GG par rapport aux patients porteurs d'un allèle À. Conclusions. Les indices hématologiques, fondés sur une analyse sanguine clinique générale étendue, sont des marqueurs cliniques non spécifiques indicatifs et fiables des troubles immunitaires en cas de CEC.

Mots-clés: marqueurs, troubles immunitaires, gènes IL-10 (rs1800872), HSP70-2 (rs1061581), coli entérite.

Abréviations: EAE - entérocolite aiguë d'Escherichia, PCT - protéines de choc thermique, IL - interleukine, CIC - cellules immunitaires compétentes, IIL - indice d'intoxication des leucocytes, LPS - lipopolysaccharides, GN - granulocytes neutrophiles.

polymorphonuclear neutrophilic granulocytes $(\mathrm{NG})$ in the first stage of disease, monocytes/macrophages of the peripheral blood and immunologic resistance $^{5-7}$. The reactive response of NG in the pathogenesis of acute AEC is crucially important, since these immune-competent cells (ICC) are one of the first to meet pathogenic and opportunistic microorganisms, are able to leave the blood stream quickly and actively attack microbes and other genetically foreign „substances“ via phagocytosis, irrespective of the place and time, supplying effective anti-infectious protection and activity of specific immune response mechanisms ${ }^{8,9}$.

During the acute phase of inflammatory changes, NG produce active oxygen forms, pro-inflammatory cytokines and chemokines, with excessive expression of free radicals in microenvironment, causing oxidative stress, damage of their own cell biomolecules, and can provide a systemic character of disease. Some receptors of NGs identify pathogen-associated molecules (CD13 - to aminopeptidase N, CD14, TLR (Toll-like Receptors) - to lipopolysaccharides (LPS) of the bacterial wall, etc); others recognize 
factors releasing into the tissues during inflammation $(\mathrm{TNF} / \mathrm{\beta R})$. In addition, NGs' surface contains receptors for interaction with $\mathrm{F}_{\mathrm{C}}$-fragments of antibodies, as well as receptors for protein fragments of the complement system C3b/C4b, CR1 (CD35), CR3 (CD11b/CD18), cytokines, etc ${ }^{10,11}$. TLRs are one of the key receptors of the natural immune system able to identify highly conservative molecular patterns in the pathogen structure (microbial ligands), initiating the development of both natural and acquired immune responses, eventually resulting in elimination of a causative agent from the body. Therefore, the change of neutrophils activity can be one of the factors determining the development and progress of pathological processes, including Escherichia coli enteritis. In case of lasting microbial contamination with pathogenic Escherichia, the antioxidant protective system fails to neutralize and eliminate the oxidation products and NGs kills themselves in the reaction of respiratory explosion, via apoptosis mainly.

Genetic background for intestinal disorders, as well as other inflammatory conditions, underwent explosive development in recent years, mainly focusing on microbiome and its relationship with metabolome and proteome, proving associations of several genes' single nucleotide polymorphisms (SNPs) with hepatitis, pancreatitis, metabolic syndrome, etc ${ }^{12-16}$. However, genetically determined susceptibility to E. coli, emphasizing development of intestinal and systemic inflammation involving NG, are not sufficiently studied.

The ObJective OF the STUDY was to investigate the role of the reactive response of polymorphonuclear NGs of peripheral blood in the systemic inflammatory response mechanisms of acute AEC depending on genes polymorphism of heat shock proteins (HSP) family 70-2 (HSP70-2, 1267A®G) and interleukin 10 (IL-10, C-592A).

\section{Material ANd methods}

The study followed the international bioethical standards (European Convention Council on Human Rights and Biomedicine) and recommendations of the Committee on Bioethics of the Ministry of Health of Ukraine. Patients' Examination Cards and Patients' Informed Consent Forms were approved by the Biomedical Ethics Commission of Bukovina State Medical University, Ministry of Health of Ukraine (Chernivtsi, UA). All enrolled patients were treated in the Infection disease Department of the Municipal Clinical Hospital Kamyanets-Podilsky city (UA), during 2014-2016. The diagnosis was based on clinical examination, history, laboratory tests, including microbiology, and coded as A04.8-A.04.9 in IDC-10. Enteropathogenic, enterotoxigenic, enteroinvasive, enterohemorrhagic, or/and enteroadhesive Escherichia coli and hemolytic intestinal bacilli (E. coli $\left.\mathrm{Hly}^{+}\right)$and lactose-negative E. coli were isolated and identified from the cavity of the colon. The patients were excluded from the study if other possible causative intestinal pathogens, like Salmonellae, Shigellae, Campylobacter etc, were identified.

After screening (matching inclusion/exclusion criteria), 95 patients with acute E. coli enteritis were selected for further examination (mean age $38.66 \pm 3.11 \mathrm{yrs}$, ranging from 25-52 yrs). Among them, $62(65.26 \%)$ were female and $33(34.74 \%)$ male. The control group included 30 healthy persons, age and gender-matched, who were not relatives with the patients.

Genomic DNA was extracted from peripheral blood leukocytes using the "DNA-sorb-B» test system, with primers specific to the gene alleles. Gene polymorphism of heat shock protein HSP70-2 (A1267G, rs1061581) and IL-10 (C-592A, rs1800872) was examined by means of polymerase chain reaction (PCR). Modified protocols with oligonucleotide primers using multiplex PCR method and further restriction fragment length polymorphism analysis was used to establish polymorphic variants of A1267G of heat shock protein HSP70-2 gene (rs1061581) and C-592A of IL-10 gene (rs1800872) ${ }^{17}$. PCR was performed using Taq-DNA-polymerase and specific primers for gene HSP70-2 (5'-CATCGACTTCTACACGTCCA-3' - forward and 5'CAAAGTCCTTGAGTCCCAAC-3' - reverse) and for gene IL-10 (5'-CCTAGGTCACAGTGACGTGG-3'-forward and 5'-GGTGAGCACTACCTGACTAGC-3' - reverse). Products of DNA fragment amplification (amplicons) of genes HSP70-2 and IL-10 were subjected to hydrolytic cleavage by endonuclease restriction enzymes PstI („Fermentas®“, Lithuania) and RsaI („Thermo Scientific", USA) accordingly.

The PCR products of IL-10 gene and HSP70-2 gene were separated by horizontal electrophoresis in $3 \%$ agarose gel stained with $4 \mu \mathrm{l}$ of ethidium bromide (45-60 minutes) and were visualized by UV transilluminator (Nyxtechnic, USA), in the presence of molecular mass ladder (100-1000 bp and 50-1000 bp), using a UV transilluminator and VitranÒ computed based program. The length of obtained restriction fragments was as follows: for HSP70-2 gene (rs1061581) - AA-genotype - 1117 base pair (bp), GG-genotype - 936 and 181 bp, and AG-genotype 1117, 936 and $181 \mathrm{bp}$; for IL-10 (rs1800872) gene AA-genotype - 236 and 276 bp, CC-genotype - 419 bp, AC-genotype - 419, 236 and 276 bp ${ }^{17}$. 
Clinical markers of immune disorders were evaluated after hematological indices ${ }^{18}$. The calculation of endogenous intoxication and cellular reactivity hematological indices and ratios was carried out on the basis of an extended general clinical blood analysis (Table 1), using haematology analyser CELL-DYN 3700 SL (manufacturer Abbott Laboratories, USA).

Statistical analysis was performed using Statistica 7.0 (StatSoft Inc, USA) software. The reliability of the data for independent quantitative samples was calculated by using Student's t-test (if distribution by Kolmogorov-Smirnov and W-Shapiro-Wilk test was close to the normal), or U-test WilcoxonMann-Whitney (in case of uneven distribution), analysis of qualitative data (categorical variables) - by odds ratio (OR), with 95\% confidence interval (CI) using a chi-square test $\left(\chi^{2}\right)(\mathrm{df}=1)$. $\mathrm{P}$ values $<0.05$ were considered statistically significant.

\section{Results}

The distribution of HSP70-2 (A1267G) gene genotypes in the study groups vs control groups was as follows: for GG-genotype $46.31 \%$ vs $50.0 \%$, for AG- $50.53 \%$ vs $50.0 \%$, and for AA-genotype - $3.16 \%$ in patients and was not found in control group, respectively. The IL-10 (rs1800872) gene distribution of polymorphic variants was as follows: for CC-genotype $52.63 \%$ vs $66.67 \%$ CA- and AA-variants in $37.89 \%$ and $9.47 \%$ vs $33.33 \%$ and there were no subjects with with AA-genotype in control group. In general, from 190 isolated alleles of both groups G-allele of HSP70-2 gene 2.52 and 3 times dominated $(p<0.001)$ and C-allele of IL-10 gene 2.52 and 5 times as much $(\mathrm{p}<0.001)$, respectively.

Some immune-hematological indices, that reflect of endogenous intoxication, cellular immunologic

Table 1. Hematological indices and ratios.

\begin{tabular}{|c|c|}
\hline Indexes, ratios, $U$ & Calculation, formulas \\
\hline Leukocyte Intoxication index (LII) by B.A. Reis, U & $(\mathrm{MC}+\mathrm{MMC}+\mathrm{PNNG}+\mathrm{SNNG}) /(\mathrm{M}+\mathrm{LIM}+\mathrm{E})$ \\
\hline Intoxication ratio, $\mathrm{U}$ & LII $x \mathrm{~L} \times \mathrm{ESR} / 1000$ \\
\hline Nuclear index of endotoxicosis degree, $\mathrm{U}$ & $(\mathrm{MMC}+\mathrm{MC}+\mathrm{PNNG}) / \mathrm{SNNG}$ \\
\hline Cellular reactivity index, $\mathrm{U}$ & $\left(\mathrm{L}_{\text {absol }} /\left(\right.\right.$ LII $\times$ Age $\left.\left._{\text {vears }}\right)\right) \times 100$ \\
\hline General resistance index, $\mathrm{U}$ & LIM / Age years $\times$ LII \\
\hline Non-specific reactivity index, $U$ & LIM x $100 /$ SNNG \\
\hline $\begin{array}{l}\text { Reactive response of Neutrophilic Granulocytes } \\
\text { (NG), U }\end{array}$ & $(\mathrm{MMC}+\mathrm{MC}+\mathrm{PNNG}) / \mathrm{SNNG}$ \\
\hline Neutrophil-Lymphocyte ratio, $U$ & $(\mathrm{MMC}+\mathrm{MC}+\mathrm{PNNG}+\mathrm{SNNG}) / \mathrm{LIM}$ \\
\hline Leukocytes shift index, $\mathrm{U}$ & $(\mathrm{B}+\mathrm{E}+\mathrm{NG}) /(\mathrm{M}+\mathrm{LIM})$ \\
\hline Neutrophil-Monocytes ratio, $\mathrm{U}$ & $(\mathrm{PNNG}+\mathrm{SNNG}) / \mathrm{M}$ \\
\hline Leucocytes-ESR ratio, $\mathrm{U}$ & $(\mathrm{L} \times \mathrm{ESR}) / 100$ \\
\hline Lymphocyte-Granulocyte ratio, $\mathrm{U}$ & $(\mathrm{LIM} \times 10) /(\mathrm{E}+\mathrm{B}+\mathrm{MMC}+\mathrm{MC}+\mathrm{PNNG}+\mathrm{SNNG})$ \\
\hline
\end{tabular}

Table 2. Immune-hematological indices of endogenous intoxication and cellular immunologic reactivity in patients with E. coli enteritis depending on polymorphic variants of gene HSP70-2 (1267A®G).

\begin{tabular}{|c|c|c|c|}
\hline \multirow{2}{*}{ Immune-hematological indices, Units } & \multirow{2}{*}{ Control group, $n=30$} & \multicolumn{2}{|c|}{ Genotypes of gene HSP70-2 in patients } \\
\hline & & AA+AG-genotypes & GG-genotype \\
\hline $\begin{array}{l}\text { Leukocyte Intoxication index (LII) by } \\
\text { B.A. Reis, U }\end{array}$ & $1.45 \pm 0.14$ & $1.90 \pm 0.16 p=0.038$ & $2.35 \pm 0.15 \mathrm{p}=0.007 \mathrm{p}_{1}=0.043$ \\
\hline Intoxication ratio, $\mathrm{U}$ & $0.03 \pm 0.01$ & $0.16 \pm 0.02 p=0.001$ & $0.22 \pm 0.03 p=0.001$ \\
\hline $\begin{array}{l}\text { Nuclear index of endotoxicosis } \\
\text { degree,U }\end{array}$ & $0.05 \pm 0.01$ & $0.14 \pm 0.01 p=0.001$ & $0.15 \pm 0.02 p=0.003$ \\
\hline Cellular reactivity index, $\mathrm{U}$ & $104.37 \pm 2.11$ & $89.02 \pm 1.86 \mathrm{p}=0.002$ & $84.46 \pm 3.05 p=0.002$ \\
\hline General resistance index, $\mathrm{U}$ & $0.156 \pm 0.02$ & $0.096 \pm 0.005 \mathrm{p}=0.005$ & $\begin{array}{c}0.078 \pm 0.006 \mathrm{p}=0.006 \\
\mathrm{p}_{1}=0.024\end{array}$ \\
\hline Non-specific reactivity index, $\mathrm{U}$ & $52.59 \pm 1.37$ & $15.07 \pm 0.60 \mathrm{p}<0.001$ & $12.39 \pm 0.55 \mathrm{p}<0.001 \mathrm{p}_{1}=0.009$ \\
\hline
\end{tabular}

Note. $\mathrm{p}$ - reliable differences concerning control group; $\mathrm{p}_{1}$ - reliable differences concerning AA+AG-genotypes carriers 
reactivity of the blood system in response to exo- and endo intoxication in patients with E. Coli enteritis, depending on polymorphic variants of HSP70-2 $(1267 \mathrm{~A} \AA \mathrm{G})$ gene, are presented in Table 2. In patients with AEC, lower levels of Cellular reactivity indices were found $-14.71 \%$ and $19.08 \%(p=0.002)$, respectively, general resistance index $-38.46 \%$ and $50.0 \%$ less ( $<<0.01$ ), and severe decrease 3.49 and 4.24 times $(\mathrm{p}<0,001)$ of non-specific anti-infectious protection by the non-specific reactivity index. Decrease was more substantial in the GG-genotype carriers of HSP70-2 $(1267 \mathrm{~A} 囚 \mathrm{G})$ gene than among $A$ allele patients $18.75 \%(p=0.024)$ and $17.78 \%(p=0.009)$ respectively. A reliably higher compensatory activation of blood immuno-competent-cells (ICC) was determined in patients with GG-genotype in response to microbial contamination of the intestines by pathogenic E. coli (after higher leukocyte intoxication index by B.A.
Reis - 23.68\% ( $\mathrm{p}=0.043)$, while intoxication indices and nuclear index of endotoxicosis degree were not found to be a clear dependence on the genotypes of HSP70-2 (1267A®G) gene, in spite of quick 2.8-7.3 times $(\mathrm{p}<0.01)$ increase.

Changes of the majority of immune-hematologic indices of endogenous intoxication and cellular reactivity in patients with E. coli enteritis, depending on polymorphic variants of IL-10 (C-592A) gene, was not found (Table 3), except for non-specific reactivity index that was reliably $12.37 \%(\mathrm{p}=0.023)$ lower in the AA-genotype carriers of IL-10 gene, than those with CC-genotype.

The activity of mechanisms and factors of non-specific anti-infectious protection in response to bacterial origin intoxication by the level of $\mathrm{NG}$ reactive response in the peripheral blood, Neutrophil-Lymphocyte coefficient, Lymphocyte-Granulocyte index, Leukocyte shift

Table 3. Immune-hematological indices of endogenous intoxication and cellular immunologic reactivity in patients with E. coli enteritis depending on polymorphic variants of gene $I L-10(C-592 A)$.

\begin{tabular}{|c|c|c|c|c|}
\hline \multirow{2}{*}{ Immune-hematological indices, Units } & \multirow{2}{*}{$\begin{array}{l}\text { Control group, } \\
\quad n=30\end{array}$} & \multicolumn{3}{|c|}{ Genotypes of gene IL-10 in patients } \\
\hline & & AA-genotype & CA- genotype & CC-genotype \\
\hline $\begin{array}{l}\text { Leukocyte Intoxication index (LII) by } \\
\text { B.A. Reis, U }\end{array}$ & $1.45 \pm 0.14$ & $2.29 \pm 0.25 \mathrm{p}<0.01$ & $2.16 \pm 0.13 p<0.01$ & $1.94 \pm 0.18 p=0.035$ \\
\hline Intoxication ratio, $\mathrm{U}$ & $0.03 \pm 0.01$ & $0.21 \pm 0.03 p<0.01$ & $\begin{array}{c}0.17 \pm 0.02 \\
p=0.001\end{array}$ & $0.18 \pm 0.02 p<0.001$ \\
\hline $\begin{array}{c}\text { Nuclear index of endotoxicosis } \\
\text { degree, } \mathrm{U}\end{array}$ & $0.05 \pm 0.01$ & $0.16 \pm 0.02 p<0.01$ & $0.14 \pm 0.02 p<0.01$ & $0.15 \pm 0.01 p<0.001$ \\
\hline Cellular reactivity index, $U$ & $104.37 \pm 2.11$ & $85.80 \pm 2.77 p<0.01$ & $\begin{array}{c}86.13 \pm 3.05 \\
p<0.01\end{array}$ & $88.52 \pm 1.95 \mathrm{p}<0.01$ \\
\hline General resistance index, $U$ & $0.156 \pm 0.02$ & $\begin{array}{c}0.079 \pm 0.005 \\
p<0.01\end{array}$ & $\begin{array}{c}0.083 \pm 0.004 \\
p<0.01\end{array}$ & $\begin{array}{c}0.090 \pm 0.006 \\
p<0.01\end{array}$ \\
\hline Non-specific reactivity index, $U$ & $52.59 \pm 1.37$ & $\begin{array}{c}12.54 \pm 0.48 \\
p<0.001\end{array}$ & $\begin{array}{c}13.26 \pm 0.52 \\
p<0.001\end{array}$ & $\begin{array}{c}14.31 \pm 0.58 p<0.001 \\
p=0.023\end{array}$ \\
\hline
\end{tabular}

Note. $\mathrm{p}$ - reliable differences concerning control group; $\mathrm{p}_{\mathrm{AA}}$ - reliable differences concerning AA-genotype carriers; $\mathrm{p}_{\mathrm{CA}}-$ reliable differences concerning CA-genotype carriers

Table 4. Reactive response of neutrophilic granulocytes in peripheral blood in patients with E. coli enteritis depending on polymorphic variants of gene $I L-10(C-592 A)$.

\begin{tabular}{|c|c|c|c|c|}
\hline \multirow{2}{*}{$\begin{array}{l}\text { Immune-hematological indices, } \\
\text { Units }\end{array}$} & \multirow{2}{*}{ Control group, $n=30$} & \multicolumn{3}{|c|}{ Genotypes of gene IL-10 in patients } \\
\hline & & AA-genotype & CA-genotype & CC-genotype \\
\hline Reactive response of NG, U & $4.71 \pm 0.44$ & $\begin{array}{c}10.44 \pm 0.58 \\
p<0.001\end{array}$ & $9.30 \pm 0.73 p<0.001$ & $9.51 \pm 0.46 p<0.001$ \\
\hline Neutrophil-Lymphocyte ratio, $\mathrm{U}$ & $1.99 \pm 0.18$ & $3.06 \pm 0.33 p=0.007$ & $2.80 \pm 0.26 \mathrm{p}=0.014$ & $2.47 \pm 0.18 p=0.047$ \\
\hline Leukocytes shift index, $\mathrm{U}$ & $1.56 \pm 0.16$ & $2.57 \pm 0.19 p=0.005$ & $2.28 \pm 0.14 p=0.009$ & $2.11 \pm 0.20 \mathrm{p}=0.035$ \\
\hline Neutrophil-Monocytes ratio, U & $6.34 \pm 0.49$ & $13.76 \pm 0.61 \mathrm{p}<0.001$ & $\begin{array}{c}12.27 \pm 0.65 \\
p<0.001\end{array}$ & $\begin{array}{c}10.79 \pm 0.53 p<0.001 \\
\mathrm{p}_{A A}=0.007\end{array}$ \\
\hline Leucocytes-ESR ratio, U & $1.41 \pm 0.15$ & $1.04 \pm 0.09 p=0.041$ & $0.99 \pm 0.08 p=0.017$ & $0.90 \pm 0.11 \mathrm{p}=0.008$ \\
\hline Lymphocyte-Granulocyte ratio,U & $4.89 \pm 0.41$ & $3.02 \pm 0.25 p=0.006$ & $3.46 \pm 0.20 \mathrm{p}=0.002$ & $\begin{array}{c}3.78 \pm 0.28 \mathrm{p}=0.029 \\
\mathrm{p}_{A A}=0.048\end{array}$ \\
\hline
\end{tabular}

Note. NG - Neutrophilic Granulocytes; $\mathrm{p}$ - reliable differences concerning control group; $\mathrm{p}_{\mathrm{AA}}$ - reliable differences concerning AA-genotype carriers; $\mathrm{p}_{\mathrm{CA}}$ - reliable differences concerning CA-genotype carriers 
index, Leukocytes-ESR ratio, NG-Monocytes ratio in patients with E. coli enteritis, did not depend on the polymorphic variants of HSP70-2 (1267A®G) gene. On the contrary, considering C-592A polymorphism of IL-10 gene (Table 4) in patients with AEC on the ground of low non-specific anti-infectious protection activity and general body resistance, in homozygous mutative $A$ allele carriers a reliably higher NG-Monocytes index was found with lower Lymphocyte-Granulocyte ratio than in CC-genotype patients - 27.52\% ( $\mathrm{p}=0.007)$ and $20.11 \%(\mathrm{p}=0.048)$ respectively.

\section{Discussion}

Polymorphonuclear NG have pleiotropic effects in immunoregulation and inflammation, that may be determined by corresponding genes encoding synthesis and activity of humoral and cells co-factors of anti-inflammatory defense ${ }^{4}$. Some researchers have determined that NG cytokines production affects the activation of Th1, Th2 cellular immune response and provides interaction of the cellular and humoral immunity link ${ }^{9-11}$. Therefore, changes of NG activity can be one of the factors determining development and progress of pathological processes, including AEC. Clinical markers (immune-hematologic indices) used in our study were indicative of bacterial infection presence in AEC patients, immune body resistance decrease, combination of immune microphage link and Th1 immunity system activation with low macrophage activity.

One of the molecular systems for protecting cells from cytotoxic reactions is HSP. HSP is a universal stress-induced cellular response including toxic action of pathogenic bacteria's LPS. HSP adapt the immune system, since they are antigenic peptides carriers from infected cells or tumours ${ }^{19}$. Immune-regulating role of HSP70 in stimulation of cytokine production is evidenced, as well as their important role in immune control over the infected area or tumor ${ }^{20,21}$. Changes in nucleotide sequence of HSP70 genes influence upon their expression or function of HSP70 proteins, causing alterations of stress-resistance mechanisms, promote increased susceptibility to pathologic conditions, including those associated with inflammatory diseases, activity of oxidative stress in diabetes mellitus patients, duodenal ulcer and stomach cancer, lymphoblastic leukemia, etc. $A \circledast G$ replacement in 1267 position of HSP70-2 gene causes changes of mRNA HSP70 expression ${ }^{22.25}$. In some studies was proved that the HSP70 expression increasing is associated with higher activity of T-helpers, plays a protective role in regulation of cellular function in case of chronic pelvic pains and chronic bacterial prostatitis syndrome, block the tumour growth factor $\beta 1$ production, decreasing inflammatory reaction and protects against bleomycin-induced pulmonary fibrosis in mice ${ }^{26,27}$. Our study is the first available of the HSP70-2 gene's A1267G SNP associations with the Escherichia enterocolitis.

The IL-10 is a regulatory anti-inflammatory cytokine produced by $\mathrm{T}$ cells, B cells, monocytes, macrophages, keratinocytes, eosinophils, mast cells and placental trophoblasts ${ }^{28}$. The IL-10 gene in humans is highly polymorphic and, at the promoter region, several single nucleotide polymorphisms have been described. IL-10 potently down-regulates the production of macrophage pro-inflammatory cytokines, such as IL-1, IL-6, IL-8, granulocyte-macrophage-colony-stimulating-factor and notably tumor necrosis factor-a, via a feedback inhibition loop ${ }^{29}$. Mutations in this gene are associated with an increased susceptibility to HIV-1 infection and rheumatoid arthritis, acute myeloid leukemia, changed expression of autocrine IL-10 signaling pathways in non-small lung cancer cells etc $^{29,30}$. However, individual studies have provided conflicting and inconclusive results: in some of them an association was established between the C592A polymorphism of the IL-10 gene and the severity and outcome of acute viral hepatitis and hepatitis-related acute liver failure, osteoarthritis, rheumatoid arthritis, but no association with juvenile idiopathic arthritis according to meta-analysis data in Caucasian or Middle Eastern participants ${ }^{31-33}$. Also, C592A polymorphism was not associated with gastrointestinal cancer risk in five genetic models, according to EMBASE, PubMed, Web of Science, and China National Knowledge Infrastructure databases' meta-analysis of case-control studies (36 studies involved 8069 cases with gastrointestinal tract cancer and 13,089 controls) $)^{34}$.

In our study, in homozygous $A$ allele carriers of IL-10 gene were reliably lower mechanisms and factors activities of anti-infectious protection, non-specific resistance with compensatory higher activation of microphage system (by the index of NG-Monocyte ratio), than in CC-genotype carriers $(\mathrm{p}<0,05)$. It highlights an important role of C592A polymorphism of IL-10 gene in immune response activity in case of bacterial invasion and possible clinical manifestation variability of Escherichiosis.

Our data indirectly confirm the high probability of the enhanced synthesis of "early" pro-inflammatory cytokines (IL-1 $\beta$, TNF-a), with insufficient production level of anti-inflammatory substances (IL-10), especially in the GG-genotype carriers of HSP70-2 gene and AA-genotype patients of IL-10 gene, that was proved in our recent study ${ }^{35}$.

Limitations of the study. The main limitation of the study is related to the small number of included patients. 


\section{Conclusions}

Thus, hematological indices, based on extended general clinical blood analysis, are indicative and reliable non-specific clinical markers of immune disorders in case of AEC. The endogenous intoxication severity did not depend reliably on polymorphic variants of IL-10 gene (rs1800872), however it was significantly higher $(23.68 \%, \mathrm{p}=0.043)$ in GG-genotype carriers of HSP70-2 (rs1061581) gene. The reduction of cellular reactivity by $14.71-19.08 \%(\mathrm{p}<0.01)$ did not depend on the analyzed genes genotypes. However, general non-specific immune reactivity decreases 3.49-4.24 times ( $<<0.001)$ was deeper in GG-genotype carriers of HSP70-2 gene and AA-genotype of IL-10 gene - by $17.78 \%(p=0.009)$ and $12.37 \%(p=0.023)$ respectively. The immunologic resistance index was lower by $18.75 \%$ ( $p=0.024)$ in the GG-genotype carriers than in subjects with $A$ allele.

\section{Compliance with Ethics Requirements:}

„The authors declare no conflict of interest regarding this article"

"The authors declare that all the procedures and experiments of this study respect the ethical standards in the Helsinki Declaration of 1975, as revised in 2008(5), as well as the national law. Informed consent was obtained from all the patients included in the study"

„All institutional and national guidelines for the care and use of laboratory animals were followed"

„No funding for this study"

\section{References}

1. World Health Organization diarrhoeal disease fact sheet page. Available at: http://www.who.int/news-room/ fact-sheets/detail/diarrhoeal-disease. Accessed January 13, 2019.

2. US Burden of Disease Collaborators. The State of US Health, 1990-2016: Burden of Diseases, Injuries, and Risk Factors among US States. JAMA 2018;319(14):1-33.

3. Desilets M, Deng Xi, Rao C, et al. Genome-based definition of an inflammatory bowel disease-associated adherent-invasive Escherichia coli pathovar. Inflamm Bowel Dis 2016; 22(1): $1-12$

4. Kobayshi SD, Voyich JM, Braughton KR, et al. Gene expression profiling provides insight into the pathophysiology of chronic granulomatous disease. J Immunol. 2004; 172(1):636-643.

5. Ivashchuk SI, Sydorchuk LP. Association of the genes IL-4 (C-590T), TNF- $\alpha$ (G-308A), PRSS1 (R122H) and CFTR (delF508C) with cytolysis syndrome activity in patients with acute edematous pancreatitis. Arch Balk Med Union 2016;51(1):41-45.

6. Maheshwari A. Immunological and hematological abnormalities in necrotizing enterocolitis. Clinics in Perinatology 2015;42(3):567.
7. Hisamatsu T, Kanai T, Mikami Y, Yoneno K, Matsuoka, $\mathrm{K}$, Hibi T. Immune aspects of the pathogenesis of inflammatory bowel disease. Pharmacology $\mathbb{E}$ Therapeutics 2013; 137(3):283-297.

8. Ivashchuk SI, Sydorchuk LP, Korovenkova OM. Level of cellular reactivity of organism and extent of intoxication severity in patients with acute pancreatitis and exacerbation of chronic pancreatitis depending on genes polymorphism CFTR, PRSS1, IL-4 and TNF- $\alpha$. Vestnik Kluba Pankreatologov 2016;1(34):21-27.

9. Urban CF, Ermert D, Schmidt M, et al. Neutrophil extracellular traps contain calprotectin, a cytosolic protein complex involved in host defense against Candida albicans. PLoS Pathog 2009; 5(10):e1000639.

10. Di Carlo E, Forni G, Lollini PL, Colomobo MP, Modesti A, Musiani P. The intriguing role of polymorphonuclear neutrophil in antitumor reactions. Blood 2001; 97:339-345.

11. Futosi K, Fodor S and Mocsai A. Neutrophil cells surface receptors and their intracellular signal transduction pathway. Int Immunopharmacol 2013;17(3):638-650.

12. Sydorchuk L, Yarynych Y, Sydorchuk A, et al. Hepatocytes' function and adipokines in patients with non-alcoholic fatty liver disease depending on the ACE (rs4646994) and PPAR-g2 (rs1801282) genes' polymorphisms. Rev Med Chir Soc Med Nat, Iași 2018; 122(2):358-364.

13. Sheremet MI, Sydorchuk LP, Shidlovskyi VO, et al. Effect of APO-1 / FAS, CTLA-4 and BCL-2 genes polymorphisms on the risk of goiter nodular forms with autoimmune thyroiditis occurrence among the Bukovinian population. Arch Balk Med Union 2017; 52(2):144-151.

14. Pol'ovyı̌ VP, Sydorchuk RI, Heorhitsa VM, Nurdinov KhN. Endoscopic treatment of hemorrhages in patients with ulcerative lesions of the gut. Klin Khir 2013; 3:17-18.

15. Sydorchuk LP, Sokolenko AA, Sydorchuk AR, et al. Insulin resistance in patients with arterial hypertension and abdominal obesity depending on ACE and PPAR- $\gamma 2$ genes polymorphism: a new opinion concerning an old problem. The New Armenian Medical J 2015; 9(2):43-51.

16. Ivashchuk SI, Sydorchuk LP, Sydorchuk AR, et al. Enzymatic activity of the pancreas as a risk factor of edematous pancreatitis development providing of genetic determination of IL-4 production. Arch Balk Med Union 2017;52(2):156-161.

17. Sydorchuk L, Syrota B, Sydorchuk A, Iftoda O, Korovenkova O, Kushnir O. Interleukins' 10 (RS1800872) and heat shock protein 70-2 (RS1061581) genes as risk markers of enterocolitis depending on cytokines production. The Pharma Innovation Journal 2018; 7(9):178-192.

18. Siplivy VA, Horse EV, Yevtushenko DV. The use of leukocyte indices to predict the outcome of peritonitis. KlInIchna Khirurhiia 2009; 9:21-26.

19. Javid B, MacAry PA, Lehner PJ. Review structure and function: heat shock proteins and adaptive immunity. J Immunol 2007;179(4):2035-40.

20. Asea A, Rehli M, Kabingu E, et al. Novel signal transduction pathway utilized by extracellular HSP70: role of toll-like receptor (TLR) 2 and TLR4. J Biol Chem 2002; 277(17):15028-34.

21. Sherman M, Multhoff G. Review heat shock proteins in cancer. Ann NY Acad Sci 2007;1113:192-201.

22. Wang Y, Zhou F, Wu Y, et al. The relationship between three heat shock protein 70 gene polymorphisms and susceptibility to lung cancer. Clin Chem Lab Med 2010;48:1657-63.

23. Mir KA, Pugazhendhi S, Paul MJ, et al. Heat-shock protein 70 gene polymorphism is associated with the severity of 
diabetic foot ulcer and the outcome of surgical treatment. $\mathrm{Br}$ J Surg 2009; 96:1205-09.

24. Partida-Rodríguez O, Torres J, Flores-Luna L, et al. Polymorphisms in TNF and HSP-70 show a significant association with gastric cancer and duodenal ulcer. Int $J$ Cancer. 2010;126:1861-68.

25. Ucisik-Akkaya E, Davis CF, Gorodezky C, et al. HLA complex-linked heat shock protein genes and childhood acute lymphoblastic leukemia susceptibility. Cell Stress Chaperones 2010;15:475-85.

26. Guo H, Xu YM, Ye ZQ, et al. Heat-shock protein 70 expression in the seminal plasma of patients with chronic bacterial prostatitis and chronic prostatitis/chronic pelvic pain syndrome. Prostate Cancer Prostatic Dis 2010;13(4):338-42.

27. Tanaka K, Tanaka Y, Namba T, et al. Heat shock protein 70 protects against bleomycin-induced pulmonary fibrosis in mice. Biochem Pharmacol 2010;80:920-31.

28. Reesa LEN, Woodb NAP, Gillespiea KM, et al. The interleukin-10 -1082 G/A polymorphism: allele frequency in different populations and functional significance. CMLS, Cell Mol Life Sci 2002; 59:01-10

29. Rashed R, Shafik RE, Shafik NF, Shafik HE. Associations of interleukin-10 gene polymorphisms with acute myeloid leukemia in human (Egypt). J Cancer Res Ther 2018; 14(5):1083-1086
30. Zhao Y, Chen S, Shen F, et al. In vitro neutralization of autocrine IL-10 affects Op18/stathmin signaling in non-small cell lung cancer cells. Oncol Rep 2019;41(1):501-511.

31. Maurya G, Hazam RK, Ruttala R, Karna R, Das BC, Kar P. A study of association between regulatory polymorphism in the IL-10 gene promoter region and acute viral hepatitis, and acute liver failure. Indian J Gastroenterol 2018;37(4):293-298.

32. Sydorchuk LP, Serdulets YuI, Sydorchuk AR, et al. The polymorphism of matrilin-3 (rs77245812) and interleukin-10 (rs1800872) genes in osteoarthritis patients with arterial hypertension, obesity and type 2 diabetes mellitus. Arch Balk Med Union 2017;52(4):422-429.

33. Harsini S, Saghazadeh A, Nedjat S, Rezaei N. Associations between interleukin-10 polymorphisms and susceptibility to juvenile idiopathic arthritis: a systematic review and meta-analysis. Eur Cytokine Netw 2018;29(1):16-26.

34. Sahami-Fard MH. Association between interleukin-10-592 A/C polymorphism and gastrointestinal tract cancer risk: A meta-analysis. Int J Biol Markers 2018;33(3):244-253.

35. Syrota BV, Sydorchuk LP. Are genes of interleukins' 10 (RS1800872) and heat shock protein 70-2 (RS1061581) predictive markers of cytokines production in patients with enterocolitis? J Education, Health and Sport 2018;8(7):615-622. 